\title{
Three New Pathogens Infecting Antilles Cherry in the State of Pará
}

\author{
Luiz S. Poltronieri ${ }^{1}$, Maria L. R. Duarte ${ }^{1}$, Acelino C. Alfenas ${ }^{2}$, Dinaldo R. Trindade ${ }^{1}$ \\ \& Fernando C. Albuquerque ${ }^{1}$
}
${ }^{1}$ Embrapa Amazônia Oriental, Tv. Dr. Eneas Pinheiro, s/n, CEP 66095-100, Belém, PA, e-mail: poltroni@cpatu.embrapa.br; ${ }^{2}$ Departamento de Fitopatologia,
Universidade Federal de Viçosa, CEP 36570-000, Viçosa, MG

(Aceito para publicação em 14/11/2002)

Autor para correspondência: Luiz S. Poltronieri

POLTRONIERI, L.S., DUARTE, M.L.R., ALFENAS, A.C., TRINDADE, D.R. \& ALBUQUERQUE, F.C. Three new pathogens infecting Antilles cherry in the State of Pará. Fitopatologia Brasileira 28:424-426. 2003.

\begin{abstract}
When grown in monoculture, Antilles cherry (Malpighia glabra) plants have been affected by diseases which cause fruits malformation and spotting, reducing their value for market. From 1999 on, three new diseases characterised by leaf spot and fall of leaves have been observed in plantations located in Santa Izabel do Pará and Igarapé Açu counties. After isolation and pathogenicity tests on leaves of Antilles cherry plants, the isolates were identified as Calonectria ilicicola (anamorph: Cylindrocladium parasiticum) which causes large leaf spots reaching up to $7 \mathrm{~cm}$ long, brownish in colour, coalescent, scorching large leaf

areas and causing 50\% of leaf fall; Corynespora cassiicola, which provokes irregularly shaped, necrotic leaf spots with dark brown margins and white centers, surrounded by a yellow halo; and Myrothecium roridum which causes greyish target spots. Corynespora cassiicola has been reported causing leaf spots on different hosts in the Amazon region, while C. cassiicola has been recorded infecting Antilles cherry besides other hosts in the States of Maranhão and Pará.

Additional keywords: new diseases, Corynespora cassiicola, Calonectria ilicicola, Myrothecium roridum, hosts.

\section{RESUMO}

Três novos patógenos associados a manchas foliares em aceroleira no Estado do Pará

Em plantios uniformes, a aceroleira (Malpighia glabra) tem sido afetada por doenças que causam manchas e malformação nos frutos, tornando estes impróprios para consumo in natura. A partir de 1999, três novas doenças caracterizadas pelo aparecimento de manchas foliares e queda da folhagem vem sendo observadas em plantações localizadas nos municípios de Santa Izabel do Pará e Igarapé Açu. Após isolamento, exame das estruturas morfológicas e testes de patogenicidade em mudas de acerola, os isolados foram identificados como Calonectria ilicicola

(anamorfo: Cylindrocladium parasiticum) que causa manchas foliares relativamente grandes atingindo até $7 \mathrm{~cm}$ de comprimento, de coloração marrom-escura que coalescem atingindo grande extensão da área foliar e causando a queda de até $50 \%$ das folhas; Corynespora cassiicola que provoca manchas necróticas de formato irregular, com bordas marromescuras e centro branco, circundadas por um halo amarelo nítido; Myrothecium roridum que causa manchas concêntricas de coloração cinza. O fungo $C$. cassiicola tem sido relatado causando doenças em vários hospedeiros na região amazônica, enquanto $C$. ilicicola infeta outros hospedeiros, nos Estados do Maranhão e Pará.
\end{abstract}

Antilles cherry (Malpighia glabra L.), originated in Central America, was introduced to Brazil in the 1950s. Antilles cherry is attractive to the pharmaceutical industries due to its high content of $\mathrm{C}$ vitamin, fourtimes greater than oranges (Manica et al., 1995). Since the 1980s, grower's cooperatives have extended cultivation to some 500 hectares, facilitating the export of fresh fruits, mainly to Japan. As climatic conditions in the State of Para are extremely favorable for growth of Antilles cherry, this fruit tree has become an attractive option replancing subsistence crops in degraded soils. However, this economically favorable scenario has been restricted by diseases that have caused damages to leaves and fruits (Trindade et al., 1993). Due to either climatic conditions or plant physiology, disease onset has been commonly seen throughout the year in fruits in different stages of development. Another problem is that chemical residues from frequent spraying makes fruits unmarketable for in natura consumption. Cuts in exports have resulted in excessive production and, consequently, prices have dropped in local markets.

When grown as a monocrop, Antilles cherry has been infected by several pathogens such as Colletotrichum gloeosporioides Penz (black speckle), Sphaceloma sp. (scab), Cercospora apii Fresen (brown spot) and root-knot nematode (Meloidogyne incognita Kafoid \& White) and M. javanica (Treub.) Chitwood and to a lesser extent Pythium deliensis Meurs already recorded by Trindade et al. (1993).

In 1999, a survey was carried out on Antilles cherry crops in the counties of Santa Izabel do Pará and Igarapé Açu in order to identify new diseases and establish control strategies to be used in a sustainable agricultural system in smallholder farms.

Antilles cherry plants showing foliar spots distinct 
Three new pathogens infecting antilles cherry in the State of Pará

from those already reported were observed. Leaf samples exhibiting different symptoms were collected in order to characterize typical symptoms of each disease and for isolating the causal organisms. Reproductive structures of the pathogens were induced after keeping diseased leaves in a moist chamber for $48 \mathrm{~h}$ and then transferring them to Petri dishes or slants containing PDA culture medium (potato 200 g; sucrose $20 \mathrm{~g}$; agar $15 \mathrm{~g}$; water $1000 \mathrm{ml}$ ).

Three fungus species were isolated. Under optical microscopy, it was observed that the first isolate produces conidiophores with globose or sub-globose vesicles and hyaline, cylindrical conidia, with one to three septa, measuring 29.5 - 33 x 4.4 - $6.6 \mu \mathrm{m}$. Red-orange perithecia containing asci, clavate in shape, with 81 and tri-septate ascospores $(43 \mathrm{x}$ $7 \mu \mathrm{m}$ ) were seen to be associated with asexual structures. These morphological characteristics are typical of Calonectria illicicola (Howley) Boedjin \& Reitsma (anamorph: Cylindrocladium parasiticum Crous, Wigfield \& Alfenas). Plants infected by $C$. parasiticum show large leaf spots, brownish in colour, measuring $7 \mathrm{~cm}$ long, coalescent, turning most of the foliar blade necrotic. Infected leaves remain attached to the branches, serving as inoculum sources for new infections (Figure 1A). The second pathogen produces greyish and obclavate or cylindrical multiseptate conidia, measuring 28.8 - $163.2 \times 4.8$ - $14.4 \mu \mathrm{m}$, formed on simple conidiophores emerging from stomata, isolate or in groups, grey in colour with three septa and bulbous base. These morphological characteristics correspong to those of Corynespora cassiicola (Berk \& Curt) Wei. It induces necrotic points ( $1 \mathrm{~mm}$ to $2 \mathrm{~mm}$ diameter), surrounded by a yellow halo. As disease progresses, those symptoms turn into irregular necrotic spots with dark brown margins, with a white centre and chlorotic halo (Figure 1B). The third pathogen causes greyish target leaf spot on both leaf surfaces (Figure 1C). It produces flat or convex sporodochia, with shiny masses of wet black spores. Masses of young spores are surrounded by a floccose and white margin. Conidia are long or ellipsoid, with round ends, hyaline to slightly olivaceous, turning dark after spore formation, measuring $4.8-8.4$ × $2.4 \mu \mathrm{m}$. These morphological characteristics are typical of Myrothecium roridum Tode ex Fr.: which has already been reported as pathogen to jute (Corchorus capsularis Ikata \& Tana) in the State of Pará (Freire et al., 1979) and Antilles cherry in the State of Ceará, in Northeastern Brazil (Freire, 1995).

Because these pathogens have been detected in different hosts other than Antilles cherry in the Amazon region, mycelial fragments of local isolates of $C$. parasiticum from yellow hardwood [Tabebuia serratifolia (Vahl) Nichols] and African mahogany (Khaya ivorensis A. Chev.); C. cassiicola from papaya (Carica papaya L.); Rhododendrum sp., from tomato (Lycopersicum esculentum Mill.) and Piper hispidinervium C. DC and, M. roridum from jute (Corchorus capsulares Ikata \& Tana) were inoculated on leaves of Antilles cherry plants to compare them with Antilles cherry isolates. Typical symptoms caused by each pathogen were observed seven days after inoculation (Table 1). All C. parasiticum and

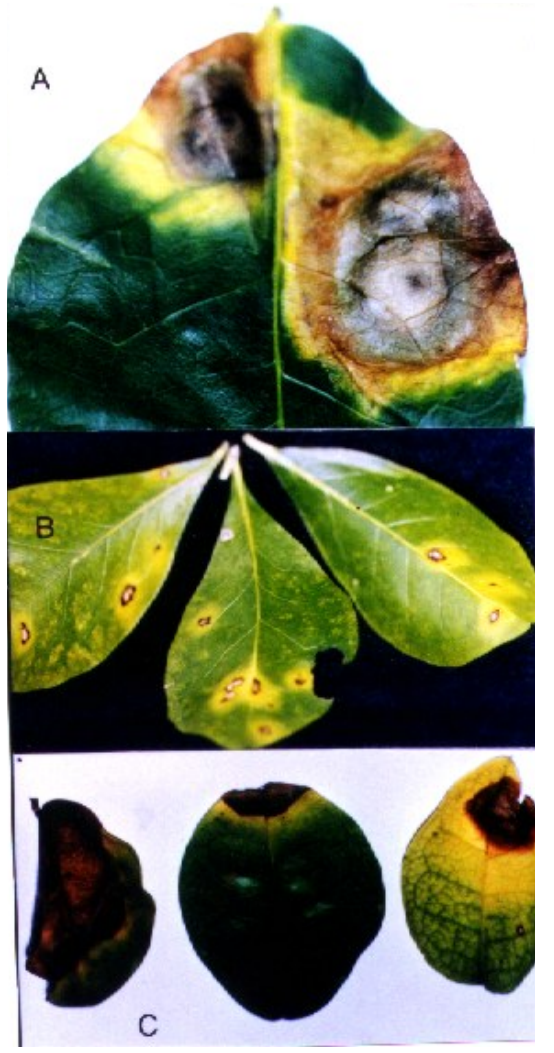

FIG. 1 - Leaf spot on Antilles cherry (Malpighia glabra)observed in field conditions. A) Cylindrocladium parasiticum; B)Corynespora cassicola e C) Myrothecium roridum.

M. roridum and most of $C$. cassiicola isolates induced symptoms on Antilles cherry leaves. However, C. cassiicola isolated from $P$. hispidinervium and papaya failed to induce symptoms on Antilles cherry suggesting that physiological variation among $C$. cassiicola isolates may be occurring. Such variation in pathogenicity was observed by Duarte et al. (1983)

TABLE 1 - Response of Antilles cherry (Malpighia glabra) plants to the infection caused by different isolates of Cylindrocladium parasiticum, Corynespora cassiicola and Myrothecium roridum

\begin{tabular}{llc}
\hline \hline Pathogen & Source of isolate & $\begin{array}{c}\text { Symptoms } \\
\text { induction }\end{array}$ \\
\hline Cylindrocladium parasiticum & Yellow hardwood & + \\
& African mahogany & + \\
& Antilles cherry & + \\
Corynespora cassiicola & Papaya & - \\
& Rhododendrumsp. & + \\
& Tomato & + \\
& Squash & + \\
& Piper hispidinervium & - \\
& Antilles cherry & + \\
Myrothecium roridum & Jute & + \\
& Antilles cherry & + \\
\hline$+=$ symptoms & &
\end{tabular}

- = no symptoms 


\section{L.S. Poltronieri et al.}

among isolates of cocoa (Theobroma cacao L.) and papaya.

Myrothecium roridum and C. cassiicola were detected on Antilles cherry for the first time by Freire (1995) and Silvaet al. (1997), respectively, Cylindrocladium parasiticum has already been recorded as causing leaf spot on Antilles cherry in the State of Maranhão (Silva et al., 2001).

\section{LITERATURE CITED}

DUARTE, M.L.R., ASANO, S. \& ALBUQUERQUE, F.C. Estudo das características morfológicas e fisiológicas de dois isolamentos de Corynespora cassiicola (Berk \& Curt) Wei. Fitopatologia Brasileira 8:205-214. 1983.

FREIRE, F.C.O. Doenças da Acerola no Brasil. In: Acerola no Brasil. Produção e Mercado. São José, A. R \& Alves, R.E (Eds). Vitória da Conquista, BA. 1995. pp.71-76.

FREIRE, F.C.O; ALBUQUERQUE, F.C \& CARDOSO, J.E. As
Doenças da Juta na Amazônia. Fitopatologia Brasileira. 4:50. 1979. (Resumo)

MANICA, I \& CARVALHO, R.I.N de. Acerola, Pesquisa e Extensão no Rio Grande do Sul. In: Acerola no Brasil. Produção e Mercado. São José, A. R \& Alves, R.E (Eds). Vitória da Conquista, BA. 1995. pp.133-141.

SILVA, G.S., RODRIGUES, A.A.C. \& SOARES JÚNIOR, A.C. Mancha de Corynespora em Acerola (Malpighia glabra L.). Fitopatologia Brasileira. 22:452. 1997. (Resumo)

SILVA, G.S., CUTRIM, F.A. \& FERREIRA, F.A. Mancha foliar e podridão de frutos da acerola causadas por Calonectria ilicícola. Fitopatologia Brasileira 26:101. 2001 (Resumo)

TRINDADE, D.R., POLTRONIERI, L.S., SILVA, H.M. \& ALBUQUERQUE, F.C. Doenças em plantios de acerola (Malpighia glabra L.) no Estado do Pará. Fitopatologia Brasileira 1:280. 1993. (Resumo) 